\title{
Comunicação
}

[Communication]

\section{Detection of double-stranded RNA viruses in fecal samples of dogs with gastroenteritis in Rio de Janeiro, Brazil}

[Deteç̧ão de vírus com genoma de RNA fita dupla em fezes de cães com gastrenterite no Rio de Janeiro, Brasil]

\author{
A.P. Costa ${ }^{1}$, R.C.N. Cubel Garcia ${ }^{2}$, N.V. Labarthe ${ }^{3}$, J.P.G. Leite ${ }^{1 *}$ \\ ${ }^{1}$ Departamento de Virologia - Instituto Oswaldo Cruz - FIOCRUZ \\ Av. Brasil, 4365 - Manguinhos \\ 21045-900 - Rio de Janeiro, RJ \\ ${ }^{2}$ Departamento de Microbiologia e Parasitologia - CMB \\ ${ }^{3}$ Depto. de Patologia e Clínica Veterinária - Faculdade de Veterinária - UFF - Niterói, RJ
}

Picobirnavirus (PBV) was first described by Pereira et al. (1988) who detected two bands of bisegmented double-stranded RNA genome by polyacrylamide gel electrophoresis (PAGE) in fecal samples from children. Since then, PBV has been detected in fecal samples of differents animals including rats (Pereira et al., 1988), avians (Alfieri et al., 1988; Leite et al., 1990), guinea pigs (Pereira et al., 1989), pigs (Gatti et al., 1989), rabitts (Gallimore et al., 1993), cattle (Vanopdenbosch and Wellemans, 1989; Khramtsov et al., 2000; Buzinaro et al., 2003) and giant anteaters (Myrmecophaga tridactyla) (Haga et al., 1999). PBV has been identified in both normal and diarrheic faeces so its pathogenicity is still unclear. This study reports the detection of PBV in fecal samples from gastroenterics dogs in the Rio de Janeiro State, Brazil.

A total of 163 fecal samples from dogs with diarrhea were collected from April 1995 to April 2001 to investigate canine parvovirus and rotavirus infections in RJ State. Ninety-four samples were obtained at Policlínica Veterinária - Universidade Federal Fluminense, and 14 samples at a private owned animal hospital, in Niterói city. Thirty-one samples came from patients of private practices at Rio de Janeiro, 13 from Teresópolis and 11 from Petrópolis. Most samples (121/163) were obtained from puppies less than seven months of age (three of them less than one month). Thirty nine samples came from dogs ranging from seven months to 13 years of age and the remaining ones from animals of unknown ages.

Picobirnavirus-positive samples were detected following the protocol used for rotavirus genome extraction. Approximately $10 \%$ fecal suspensions were prepared in $0.01 \mathrm{M}$ Tris-HCl$0,0015 \mathrm{M} \mathrm{Ca}^{+2}, \mathrm{pH} 7.2$, and viral dsRNA was extracted using guanidine isothiocyanate buffer and silica, as previously described by Boom et al. (1990). The dsRNAs were analyzed by PAGE as described by Pereira et al. (1988) with minor modifications. The electrophoresis was carried out in $7.5 \%$ acrylamide gels run either in $15 \mathrm{~cm}$ wide, $12 \mathrm{~cm}$ high, $0.1 \mathrm{~cm}$ thick chambers at $35 \mathrm{~mA}$ for four hours or in $9 \mathrm{~cm}$ wide, $7 \mathrm{~cm}$ high, $0.1 \mathrm{~cm}$ thick at $25 \mathrm{~mA}$ for $1.5 \mathrm{~h}$. Gels were silver nitratestained as described by Herring et al. (1982). The segment lengths were estimated by comparison with the length of genome segments of simian rotavirus SA11 and a human fecal sample positive for rotavirus.

Recebido para publicação em 5 de novembro de 2003

Recebido para publicação, após modificações, em 13 de abril

de 2004

*Autor para correspondência

E-mail: jpgleite@ioc.fiocruz.br 
Three presented the dsRNA genome, whose bands were found between segments 3 and 5 when compared to the rotavirus segments. The size of the segments was estimated to be from 2.69 to $2.36 \mathrm{Kbp}$ for the larger and from 2.36 to $1.58 \mathrm{Kbp}$ for the smaller segments (Fig. 1). Two out of three samples were from dogs less than six months of age and one of them was also positive for canine parvovirus. Three segments of dsRNA suggestive of picotrirnavirus (PTV) (Leite et al., 1990) were also observed in another sample of a three-month old dog. Ten segments of dsRNA were found in one sample, suggesting the presence of reovirus. No sample was found to be positive for rotavirus.

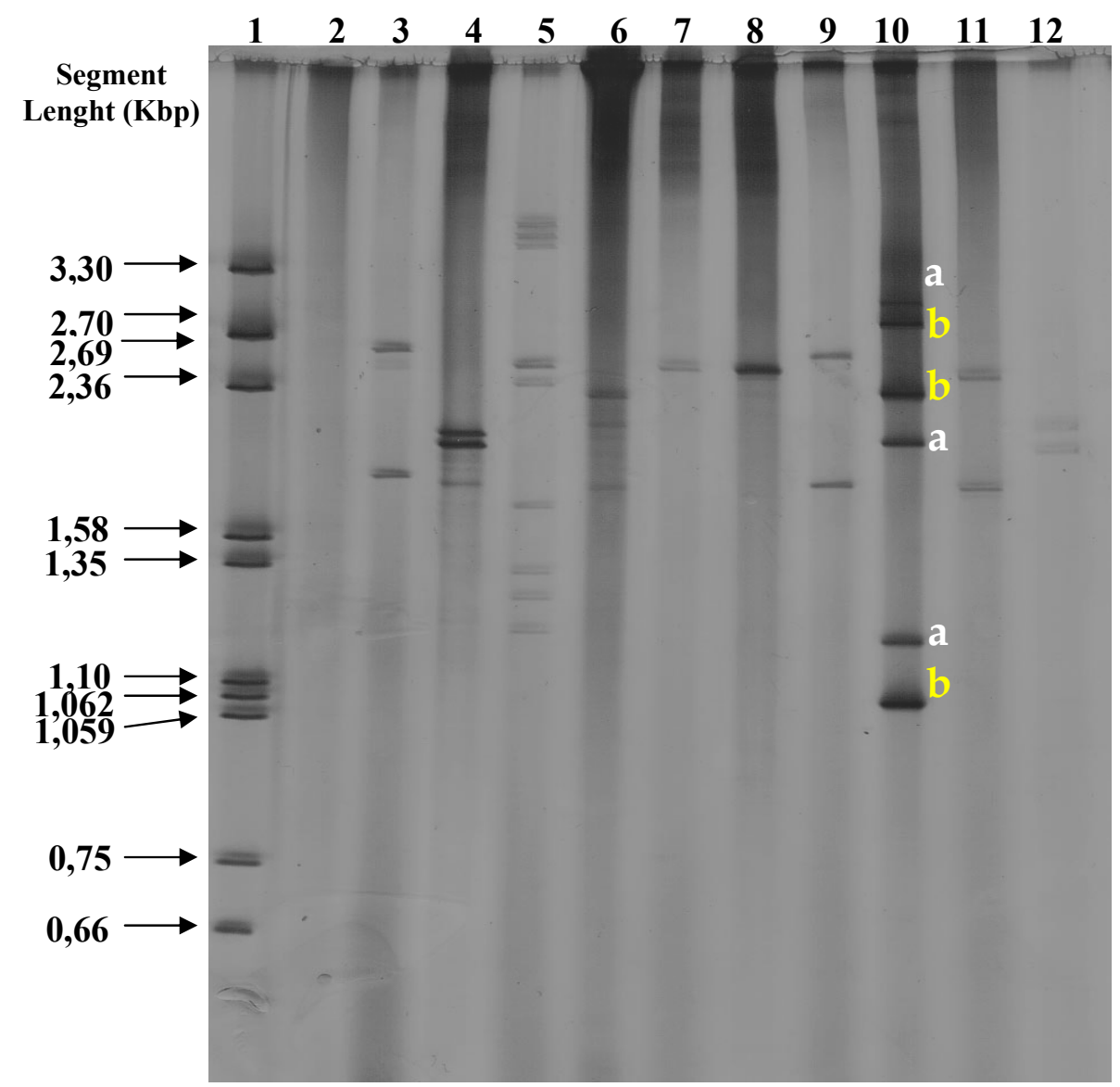

Figure 1. Differents electrophoretics profiles of dsRNA viruses from dogs fecal samples: Lane 1 - human rotavirus genotype $\mathrm{P}[8], \mathrm{G} 1$ strain; lanes 3, 9 and 11 - picobirnavirus; lane 10 - double picotrirnavirus infection $(\mathrm{a}+\mathrm{b})$; lane 5 - reovirus like; lanes $2,4,6,7,8$ and 12 - negative samples.

Recently, in Brazil, PBV has been detected by PAGE in faeces of diarrheic and non-diarrheic calves (Buzinaro et al., 2003). PTV has been described in two studies with chickens (Leite et al., 1990; Monteiro et al., 1991), one study among children with diarrhea (Ludert and
Liprandi, 1993) and one study with dogs in Rio de Janeiro (Volotão et al., 2001). In this study it was possible to detect PBV and PTV in fecal samples of $1.8 \%$ and $0.6 \%$ of dogs suffering from gastroenteritis, respectively. Similar results were previously found for PBV (1.8\%) and PTV 
$(0.45 \%)$ in fecal samples from children (Pereira et al., 1988; Ludert and Liprandi, 1993).

The detection of PBV and PTV has been done by PAGE, because this methods has the ability to sufficiently fractionate the viral RNA from other nucleic acids in the stool samples showing distinct profiles (Rosen et al., 2000). Considerable diversity in the PAGE dsRNA electrophoretic profiles has been observed among PBV (Gallimore et al., 1993; Green et al., 1999). Molecular methodologies as reversetranscription polymerase chain reaction (RTPCR) (Green et al., 1999; Rosen et al., 2000) and Northern blot (Green et al., 1999) have been used to detect and characterize PBV and PTV unsuccessfully. Green et al. (1999) demonstrated by Northern blot that the amplicon obtained by
RT-PCR assay hybridised only with the dsRNA extracted from the rabbit original sample, failing to hybridise with dsRNA extracted from others rabbits and humans. Therefore, PAGE methodology continues to be the suitable technique to detect segmented viruses (Ludert and Liprandi, 1993).

The present study is the first report of a bisegmented double-stranded RNA virus identified in diarrheic dogs in Brazil. Further studies should be carried on to elucidate the real importance of this virus infection in human and animals.

Keywords: dog, picobirnavirus, gastroenteritis, polyacrylamide gel electrophoresis

\section{RESUMO}

Colheram-se 163 amostras fecais no periodo de 1995 a 2001 para investigar a ocorrência da infecção por parvovírus e rotavírus em cães com gastrenterite utilizando-se a técnica de eletroforese em gel de poliacrilamida. Em três amostras observou-se a presença do genoma bisegmentado similar ao perfil eletroforético dos picobirnavirus (PBV) e em uma, três segmentos de RNA dupla fita, característico de picotrirnavirus. Das amostras positivas para $P B V$, duas foram obtidas de filhotes e uma foi positiva para parvovírus canino. Este é o primeiro relato da detecção de vírus com genoma bisegmentado em cães com diarréia no Estado do Rio de Janeiro.

Palavras-chave: cão, picobirnavirus, gastrenterite, eletroforese em gel de policrilamida

\section{ACKNOWLEDGEMENTS}

The authors wish to thank the clinical practicioners from Policlinica Veterinária / UFF and other private hospitals, who generously provided fecal samples for testing. This work was supported by Brazilian Research Council (CNPq), FAPERJ, and Instituto Oswaldo Cruz. A. P. Costa received CNPq fellowship due to his Graduate Program (MSc) at Instituto Oswaldo Cruz, FIOCRUZ.

\section{REFERENCES}

ALFIERI, A.F.; ALFIERI, A.A.; RESENDE, J.S. et al. A novel bisegmented double-stranded RNA virus in avian faeces. Arq. Bras. Med. Vet. Zootec., v.40, p.437-440, 1988.
BOOM, R.; SOL, C.J.A.; SALIMANS, M.M.M. et al. Rapid and simple method for purification of nucleic acids. J. Clin. Microbiol., v.26, p.495503, 1990.

BUZINARO, M.G.; FREITAS, P.P.; KISIELLIUS, J.J. et al. Identification of a bisegmented double-stranded RNA virus (picobirnavirus) in calf faeces. Vet. J., v.166, p.185-187, 2003.

GALLIMORE, C.; LEWIS, D.; BROWN, D. Detection and characterization of a novel bisegmented double-stranded RNA virus (picobirnavirus) from rabbit faeces. Arch. Virol., v.133, p.63-73, 1993.

GATTI, M.S.V.; PESTANA, P.; CASTRO, A.F. et al. Viruses with bisegmented double-stranded RNA in pig faeces. Res. Vet. Sci., v.47, p.397398, 1989. 
GREEN, J.; GALLIMORE, C.I.; CLEWLEY, J.P. et al. Genomic characterisation of the large segment of a rabbit picobirnavirus and comparison with the atypical picobirnavirus of Cryptosporidium parvum. Arch. Virol., v.144, p.2457-2465, 1999.

HAGA, I.R.; MARTINS, S.S.; HOSOMI, S.T. et al. Identification of a bisegmented doublestranded RNA virus (Picobirnavirus) in faeces of giant anteaters (Myrmecophaga tridactyla). Vet. J., v.158, p.234-236, 1999.

HERRING, A.J.; INGLIS, N.F.; OJHE, C.K. et al. Rapid diagnosis of rotavirus infection by direct detection of a viral nucleic acid in silversatined polyacrylamide gels. J. Clin. Microbiol., v.16, p.473-477, 1982.

KHRAMTSOV, N.V.; CHUNG, P.A.; DYKSTRA, C.C. et al. Presence of doublestranded RNAs in human and calf isolates of Cryptosporidium parvum. J. Parasitol., v.86, p.275-282, 2000.

LEITE, J.P.G.; MONTEIRO, A.M.; FIALHO, A.M. et al. A novel avian virus with trisegmented double-stranded RNA and further observations on previously described similar viruses with bisegmented genome. Virus Res., v.16, p.119-126, 1990.

LUDERT, J.E.; LIPRANDI, F. Identification of viruses with bi-and trisegmented double-stranded
RNA genome in faeces of children with gastroenteritis. Res. Virol., v.144, p.219-224, 1993.

MONTEIRO, S.P.; FIALHO, A.M.; PEREIRA, H.G. et al. Viruses with segmented doublestranded RNA in chickens. Arq. Bras. Med. Vet. Zootec., v.43, p.141-146, 1991.

PEREIRA, H.G.; DE ARAUJO H.P.; FIALHO, A.M. et al. A virus with bisegmented doublestranded RNA genome in guinea pig intestines. Mem. Inst. Oswaldo Cruz, v.84, p.137-140, 1989.

PEREIRA, H.G.; FLEWETT, T.H.; CANDEIAS, J.A.N. et al. A virus with a bisegmented double-stranded RNA genome in rat (Oryzomys nigripes) intestines. J. Gen. Virol., v.69, p.2749-2754, 1988.

ROSEN, B.I.; FANG, Z.; GLASS, R.I. et al. Cloning of human picobirnavirus genomic segments and development of na RT-PCR detection assay. Virology, v.277, p.316-329, 2000 .

VANOPDENBOSCH, E.; WELLEMANS, G. Birna-type virus in diarrhoeic faeces. Vet. Rec., v.125, p.610, 1989.

VOLOTÃO, E.M.; SOARES, C.C.; ALBUQUERQUE, M.C.M. et al. First evidence of a trisegmented double-stranded RNA virus in canine faeces. Vet. J., v.161, p.205-207, 2001. 